\title{
PEMANFAATAN KULIT BUAH MANGGIS UNTUK PEWARNA AGAR- AGAR SEBAGAI BAHAN AJAR PADA MATERI ILMU KIMIA DAN PERANANNYA
}

\author{
Rehamita Siregar *, Yusbarina Yusbarina
}

Program Studi Pendidikan Kimia Fakultas Tarbiyah dan Keguruan, Universitas Islam Negeri Sultan Syarif Kasim Riau, 28293, Riau, Indonesia

\begin{tabular}{l}
\multicolumn{1}{c}{ Informasi Artikel } \\
\hline Sejarah Artikel: \\
Diterima: $31-12-2020$ \\
Disetujui : 26-01-2021 \\
Dipublikasikan: 29-01-2021 \\
\hline Keywords: \\
Teaching material, \\
poster, \\
Garcinia mangostana. L, \\
Zat warna anthocyanin \\
\hline
\end{tabular}

\begin{abstract}
A b s t r a k
Tujuan dari penelitian ini adalah untuk mengetahui kelayakan bahan ajar berupa poster pada materi Ilmu Kima dan Peranannya yang dibuat berdasarkan hasil penelitian laboratorium ekstraksi antosianin dari kulit buah manggis yang dijadikan untuk pewarna alami pada agar-agar. Metode yang digunakan pada penelitian adalah mixed methods dengan strategi eksploratoris sekuensial. Penelitian ini dilakukan dua tahapan, tahap pertama adalah tahap kualitatif yaitu melakukan analisis kurikulum. Hasil ekstraksi antosianin kulit buah manggis dengan metode $\mathrm{pH}$ diferensial menunjukkan kandungan antosianin dari kulit buah manggis sebesar 42,214 mg/l. Hasil uji organoleptik terhadap 25 panelis terhadap rasa varian konsentrasi ekstrak antosianin 10, 20, 30, $40 \%$, ekstrak yang paling disukai panelis adalah $10 \%$. Penambahan ekstrak antosianin pada agar-agar dengan konsentrasi yang berbeda menunjukkan pengaruh terhadap warna agar-agar, tetapi tidak menunjukkan pengaruh terhadap rasa agar-agar. Pemanfaatan ekstrak antosianin kulit buah manggis untuk agar-agar dikembangkan menjadi bahan ajar berupa poster dan dilakukan validasi, hasil validasi yang didapatkan adalah sebesar $80 \%$ dengan kategori baik.
\end{abstract}

\section{A b s tract}

This research aimed at knowing the feasibility of teaching materials in the from of posters on the science of chemistry and its role based on the result of research on anthocyanin extraction from mangosteen rind wich is used for agar-agar. Mixed methods with sequential exploratory strategy was used in this research. This research was conducted in two stage, the first stage was the quantitative stage, namely conducting curriculum analysis. The second stage is quantitative, namely by making teaching materials. The result of anthocyanin extraction of mangosteen rind using the differential $\mathrm{pH}$ method showed that the anthocyanin content of the mangosteen rind was $42.214 \mathrm{mg} / \mathrm{l}$. The organoleptic test results of 25 panelists on the flavor variants of anthocyanin extract concentrations of $10 \%, 20 \%, 30 \%$ and $40 \%$, the most preferred extract by panelists was $10 \%$. The addition of anthocyanin extracts to agar-agar with different concentrations showed an effect on the color of the agar, but did not show an effect on the taste of the jelly. Utilization of mangosteen rind anthocyanin extract for agar is developed into teaching materials in the form of posters and validation is carried out, the validation results 
(C) 2021 JPK UNRI. All rights reserved

*Alamat korespondensi:

e-mail: rehamitas@gmail.com

No. Telf: +6282273189539

\section{PENDAHULUAN}

Implementasi kurikulum 2013 diharapkan mampu menjadikan generasi penerus bangsa yang produktif, inovatif dan afektif. Hal tersebut dapat diwujudkan melalui penguatan sikap, keterampilan dan pengetahuan yang terintegrasi. Dalam implementasi kurikulum 2013 guru mempunyai peran yang besar untuk merancang pembelajaran efektif dan bermakna. Guru dituntut untuk dapat merancang model, metode, strategi dan menyediakan sumber belajar untuk menunjang proses belajar mengajar sehingga dapat meningkatkan motivasi peserta didik untuk mencapai kompetensi pembelajaran (Mulyasa, 2013).

Motivasi adalah faktor yang dapat meningkatkan kualitas pembelajaran. Peserta didik dapat meningkatkan kualitas belajar jika memiliki motivasi belajar yang tinggi. (Mulyasa, 2013). Salah satu cara yang dapat dilakukan untuk meningkatkan motivasi peserta didik, adalah dengan menghubungkan pembelajaran dengan kehidupan sehari-hari peserta didik atau kehidupan nyata peserta didik (pembelajaran kontekstual) (Hartono, 2013). Berdasarkan hasil penelitian yang telah dilakukan Lilia dan Widodo, (2014) implementasi pembelajaran kontekstual pada materi reaksi redoks dengan percobaan sederhana berbasis alam lingkungan mampu meningkatkan motivasi belajar peserta didik. Hal ini karena peserta didik dapat langsung menghubungkan materi reaksi redoks dengan contoh yang terdapat di lingkungan sehari-hari peserta didik melalui percobaan sederhana.

Salah satu hal yang dapat dikembangkan untuk meningkatkan motivasi peserta didik adalah dalam pengembangan bahan ajar. Bahan ajar merupakan segala bahan seperti informasi, alat maupun teks yang disusun secara sistematis. Bahan ajar tersebut akan digunakan oleh guru dan peserta didik dalam melaksanakan proses pembelajaran (Prastowo, 2014). Kurikulum yang terus berkembang sesuai dengan perkembangan zaman menuntut agar bahan ajar yang disusun bersifat kekinian atau up to date (Sari, et al.,2014). Bahan ajar yang dibuat harus sesuai dengan kurikulum yang berlaku saat ini agar tujuan pembelajaran dapat tercapai (Setiowati, et al., 2017). Serta bahan ajar up to date juga dapat dibuat dari hasil penelitian (Sari, et al., 2014).

Penggunaan bahan ajar yang sesuai dapat meningkatkan motivasi dan minat peserta didik (Setiowati, et al., 2017). Oleh karena itu dibutuhkanlah suatu bahan ajar yang sesuai dengan kurikulum yang berlaku dan berdasarkan hasil penelitian laboratorium agar tujuan pembelajaran dapat tercapai. Sejalan dengan hasil penelitian laboratorium yang kemudian disusun menjadi bahan ajar yang dilakukan Wulandari, (2016) tentang pengaruh berbagai konsentrasi ekstrak bunga mawar (Rosa damascene Mill) terhadap stabilitas warna antosianin agar - agar sebagai sumber belajar biologi. Hasil penelitian tersebut terdapat pengaruh berbagai konsentrasi ekstrak bunga mawar merah terhadap stabilitas warna antosianin pada agar-agar. Kemudian hasil penelitian laboratorium tersebut disusun sebagai sumber belajar. Penelitian laboratorium dapat disusun menjadi suatu sumber belajar disesuaikan KD 3.10 jenjang pendidikan SMA sehingga sumber belajar dapat menunjang proses pembelajaran.

Poster merupakan bahan ajar yang dapat dikembangkan berdasarkan hasil penelitian laboratorium. Poster merupakan penggabungan kombinasi visual dari gambar, garis dan warna (Rizawayani, et al., 2017). Poster dapat menarik perhatian dan meningkatkan motivasi peserta didik dalam proses pembelajar (Niska, 2013). Bahan ajar yang disusun dari hasil penelitian ekstraksi antosianin kulit buah manggis dibuat dalam bentuk poster dapat menjadi materi pendukung dalam 
pokok bahasan ilmu kimia dan peranannya. Hal ini sesuai dengan tujuan pembelajaran kimia SMA kelas X pada kompetensi dasar 3.1. Berdasarkan penelitian yang dilakukan Rizawayani, et al., (2017) tentang pengembangan media poster pada materi struktur atom di SMA Negeri 12 Banda Aceh hasil validitas menunjukkan nilai rata-rata $82,53 \%$ yang dikategorikan bahwa media poster yang dikembangkan sangat layak dan dapat digunakan sebagai media pembelajaran dan merupakan bahan ajar yang dapat menerapkan konsep materi yang abstrak sehingga dapat membantu peserta didik dalam memahami materi struktur atom dengan baik dan optimal.

Berdasarkan hasil penelitian ekstrak antosianin kulit buah manggis kemudian diterapkan dalam penggunaannya sebagai pewarna alami pada makanan khususnya pada agar-agar. Antosianin terdapat pada sayur dan buah-buahan berwarna merah hingga biru seperti pada kulit buah manggis antosianin memberi warna keunguan. Antosianin memberi manfaat bagi kesehatan tubuh menurut JEFCA (Joint FAO/WHO Expert Committee on Food Additives) menyatakan bahwa ekstrak yang mengandung antosianin mempunyai efek toksisitas yang rendah, dapat mengurangi resiko penyakit jantung coroner, resiko stroke, aktivitas antikarsinogenik, efek anti inflamasi, memperbaiki ketajaman mata (Santoni, et al., 2013).

Hal ini memberi contoh bahwa peranan ilmu kimia yang dapat diterapkan dalam kehidupan sehari-hari peserta didik. Peserta didik dapat mengenali zat alami yang berasal dari kulit buah manggis dapat digunakan dalam pewarna makanan. Sehingga peserta didik mengetahui bahwa pewarna alami dari tumbuhan lebih sehat dari pada pewarna sintesis. Serta peserta didik dapat menerapkan pengurangan pewarna sintesis, karena penggunaan pewarna sintesis perlu memperhatikan aturan pemakaian. Jika terjadi penyalahgunaan pewarna sintesis dapat menyebabkan penyakit yang berisiko seperti kanker kulit, kanker mulut, kerusakan otak dan lain-lain (Fauziyah, et al., 2016). Kemudian pewarna antosianin yang diperoleh dari kulit buah manggis ditambahkan pada makanan yaitu agaragar.

Agar-agar dipilih dalam penambahan pewarna antosianin dari kulit buah manggis karena agaragar merupakan makanan yang sangat baik untuk pencernaan dan penambahan nutrisi dalam tubuh, hal ini dikarenakan agar-agar terbuat dari rumput laut. (Sukhriwati, 2015). Terkini beberapa bahan alam telah dimanfaatkan sebagai bahan pembelajaran. Daesusi et al., (2018) telah menggunakan kulit buah durian sebagai bahan ajar pada materi pengelolaan limbah. Maulidiyah, (2012) telah memanfaatkan ekstrak kulit manggis dalam bentuk segar dan kering sebagai bahan ajar mikrobiologi. Berdasarkan latar belakang di atas, maka dilakukan penelitian mengenai pemanfaatan ekstrak antosianin dari kulit buah manggis (Garcinia mangostana L) untuk pewarna agar-agar sebagai bahan ajar poster untuk menunjang proses pembelajaran yang menghubungkan dengan kehidupan sehari-hari peserta didik pada materi ilmu kimia dan peranannya pada kelas X SMA.

\section{METODE PENELITIAN}

Metode penelitian yang digunakan pada penelitian ekstrak antosianin kulit buah manggis untuk agar-agar sebagai bahan ajar pada materi ilmu kimia dan peranannya adalah metode penelitian kombinasi (mixed methods). Penelitian kombinasi merupakan metode penelitian yang mengombinasikan antara metode kuantitatif dengan metode kualitatif. Strategi yang digunakan adalah strategi eksploratoris sekuensial (Sanjaya, 2014). Tahap pertama penelitian ini adalah mengumpulkan dan menganalisis data kualitatif. Analisis bahan ajar dilakukan dengan menggunakan rating scale (Riduwan, 2007) yang diperoleh dengan beberapa langkah berikut;

a. Menentukan skor maksimal ideal

b. Menentukan skor yang diperoleh dengan menjumlahkan skor dari validator

c. Menentukan persentase keidealan

Setelah pengumpulan data kualitatif tahap selanjutnya adalah mengumpulkan dan menganalisis data kuantitatif. Analisis kuantitatif pada penelitian ini adalah penelitian yang dilakukan 
di laboratorium untuk mendapatkan ekstrak antosianin pada kulit buah manggis yang akan digunakan sebagai pewarna alami pada agar-agar (Suzery, et al. 2011). Penentuan kadar total antosianin dari kulit buah manggis menggunakan metode $p H$ differential ditunjukan Persamaan 1 (Hayati, et al. 2012).

$\mathrm{A}=\left(\mathrm{A}_{510}-\mathrm{A}_{700}\right)_{\mathrm{pH} 1,0}-\left(\mathrm{A}_{510}-\mathrm{A}_{700}\right)_{\mathrm{pH}} 4,5$

Kandungan pigmen antosianin pada sampel dihitung dengan menggunakan Persamaan 2:

Antosianin $(\mathrm{mg} / \mathrm{l})=\frac{\mathrm{A} \times \mathrm{MW} \times \mathrm{DF} \times 1000}{\varepsilon \times 1}$

Dimana, $\varepsilon$ adalah absorptivitas molar $\left(269001 . \mathrm{mol}^{1} \cdot \mathrm{cm}^{-1}\right), 1$ ialah lebar kuvet, MW yaitu berat molekul sianidin-3glukosida (449,2 g/ g mol), Vd adalah volume akhir pengenceran dan $\mathrm{Wd}$ adalah berat ekstrak kering (g). Hasil penelitian ekstrak antosianin dari kulit buah manggis kemudian diaplikasikan sebagai pewarna alami pada agar-agar. Kemudian agar-agar yang telah ditambahkan pewarna alami dari ekstrak kulit buah manggis dilakukan uji organoleptik. Uji organoleptik yang digunakan adalah uji hedonik.

Uji hedonik dilakukan untuk menentukan variasi mana yang lebih disukai panelis (Ayustaningwarno,F.,2014). Uji hedonik dilakukan menggunakan metode angket terhadap 25 panelis agak terlatih. Uji hedonik dengan parameter warna dan rasa agar - agar dengan pewarna ekstrak kulit manggis dengan konsentrasi 10\%, 20\%,30\%, 40\%. Data yang diperoleh kemudian dianalisis dengan variansi anova satu jalur (Siregar,S.,2013). Selanjutnya barulah dibuat menjadi bahan ajar berupa poster. Kelayakan bahan ajar yang dibuat akan divalidasi oleh ahli materi dan ahli kimia. Waktu dilaksanakannya penelitian ini adalah April-Juli 2017. Penelitian dilakukan di Laboratorium Patologi, Etimologi dan Mikrobiologi, Fakultas Pertanian dan Peternakan.

\section{HASIL DAN PEMBAHASAN}

\section{a. Analisis Kebutuhan}

Analisis kebutuhan bahan ajar adalah suatu proses awal yang dilakukan untuk menyusun bahan ajar. Didalamnya terdiri atas tiga tahap yaitu, analisis terhadap kurikulum, analisis sumber belajar, dan penentuan serta judul bahan ajar yang harus dipahami peserta didik (Prastowo, 2004). Matriks analisis kurikulum ditunjukkan pada Tabel 1.

Tabel 1. Matriks Analisis Kurikulum

\begin{tabular}{llcc}
\hline \multicolumn{1}{c}{ Kompetensi dasar } & \multicolumn{1}{c}{ Indikator } & Materi pokok & Jenis Bahan Ajar \\
\hline 3.1 Memahami hakikat ilmu & 3.1.1 Menjelaskan & Ilmu kimia & Poster \\
kimia, metode ilmiah dan & hakikat ilmu kimia & dan & \\
keselamatan kerja di & dan peranannya dalam & peranannya & \\
laboratorium serta peranan & kehidupan sehari hari & & \\
kimia dalam kehidupan. & & & \\
\hline
\end{tabular}

Tahapan proses penelitian ini dapat digunakan untuk mencapai tujuan pembelajaran kimia SMA kelas X pada kompetensi dasar 3.1. Berdasarkan analisis kurikulum maka diperoleh kompetensi dasar, indikator, materi pokok dan jenis bahan ajar pada tabel 1. Berdasarkan analisis sumber belajar, maka penelitian pemanfaatan ekstrak antosianin sebagai bahan ajar dapat digunakan sebagai bahan ajar karena memenuhi kriteria ketersediaan, kesesuaian dan kemudahan sebagai bahan ajar. Berdasarkan penelitian yang dilakukan Wulandari, (2016) tentang Pengaruh Berbagai Konsentrasi Ekstrak Bunga Mawar (Rosa damascene Mill) terhadap stabilitas warna antosianin agar-agar sebagai sumber belajar 
biologi menunjukkan hasil penelitian adanya pengaruh berbagai konsentrasi ekstrak bunga mawar merah terhadap stabilitas warna antosianin agar-agar. Hasil penelitian dapat diterapkan sebagai sumber belajar karena objek dalam penelitian ini sesuai dengan KD 3.10 jenjang pendidikan SMA.

Berdasarkan prinsip relevansi, konsistensi dan kecukupan maka dipilih dan ditentukan bahan ajar berupa poster. Bahan ajar yang dibuat termasuk ke dalam aspek kognitif. Aspek kognitif tersebut meliputi fakta, konsep dan prinsip. Fakta, konsep dan prinsip dari hasil penelitian diringkaskan pada Tabel 2.

Tabel 2. Fakta, Konsep dan Prinsip dari Hasil Penelitian

\begin{tabular}{lll}
\hline \multicolumn{1}{c}{ Fakta } & \multicolumn{1}{c}{ Konsep } & \multicolumn{1}{c}{ Prinsip } \\
\hline Pada kulit buah manggis & Antosianin adalah zat & Kulit buah manggis yang \\
terdapat kadungan & pewarna alami yang & mengandung antosianin dapat \\
senyawa kimia antosianin & membentuk pigmen & dijadikan pewarna pada agar- \\
yang memberikan warna & warna merah, ungu & agar sehingga agar-agar dapat \\
pada kulit buah manggis. & dan biru pada tanaman & merwarna kemerahan \\
\hline
\end{tabular}

Poster termasuk ke dalam media berbasis teks, ada beberapa cara untuk menarik perhatian peserta didik pada media berbasis teks yaitu; warna, huruf, dan kotak. Warna digunakan sebagai alat penuntun dan menarik perhatian informasi yang penting. Poster meliputi tiga komponen yaitu judul, kompetensi dasar atau materi pokok dan informasi pendukung.

\section{b. Pembuatan Bahan Ajar}

Tahap pembuatan ekstrak antosianin dari kulit buah manggis untuk agar-agar dipilih kulit manggis yang berwarna ungu kehitaman. Kulit buah manggis dibuat menjadi serbuk kulit buah manggis yang kemudian akan diekstraksi. Proses ekstraksi yang digunakan untuk mendapatkan ekstrak antosianin kulit buah manggis adalah ekstraksi maserasi, karena sampel yang digunakan tidak tahan panas dan pengerjaannya cukup sederhana. Senyawa antosianin relatif rentan terhadap panas sehingga dikhawatirkan akan merusak senyawa bahkan menghilangkan senyawa yang akan dianalisis (Hayati, E,K, et al., 2012).

Ekstraksi dilakukan dengan menggunakan rasio perbandingan pelarut air : asam sitrat (1:4). Digunakan pelarut air karena air memiliki kepolaran yang sama dengan kepolaran antosianin, air dan antosianin sama-sama bersifat polar (Wulaningrum, R,A., 2013). Sedangkan pelarut asam sitrat 10\% digunakan karena sifat asam yang akan menyebabkan warna antosianin menjadi merah. Hal ini berpengaruh terhadap jumlah gugus metoksi yang dominan dibandingkan gugus hidroksil pada struktur antosianidin, menyebabkan warna cenderung merah dan relatif stabil (Supiyanti, W., 2010). Ekstrak antosianin dari kulit buah manggis yang diperoleh berwarna jingga kemerahan. Warna jingga kemerahan ini merupakan pengaruh xanthon yang memberikan warna kuning dan antosianin yang mempunyai warna merah keunguan (Gupita, 2012).

Ekstrak antosianin kemudian dilakukan uji kualitatif. Uji kualitatif dilakukan dengan menggunakan spektrofotometer UV-Vis untuk menentukan panjang gelombang antosianin kulit buah manggis. Dari hasil pengukuran panjang gelombang diperoleh panjang gelombang maksimum 510 $\mathrm{nm}$. Panjang gelombang maksimum $510 \mathrm{~nm}$ menunjukkan pada kulit buah manggis terdapat senyawa antosianin. Senyawa antosianin mempunyai karakteristik dua daerah serapan pada panjang gelombang UV (260-280 $\mathrm{nm})$ dan visibel $(490-550 \mathrm{~nm})$ dan diukur dengan alat spektrofotometer UV-Vis (Santoni, et al., 2013).

Setelah didapatkan panjang gelombang maksimum, selanjutnya dilakukan pengukuran kadar antosianin dengan menggunakan metode $\mathrm{pH}$ diferentsial. Penetapan konsentrasi antosianin dengan metode ini dikarenakan pada $\mathrm{pH}$ 1,0 antosianin membentuk senyawa oxonium (kation flavilium) yang berwarna dan pada pH 4,5 berbentuk karbinol/ hemiketal tak berwarna (Wulaningrum, R, A., 2013). 
Kondisi inilah yang akan dijadikan acuan untuk menentukan absorbansi dengan menggunakan spektrovotometri UV-Vis dari masing-masing ekstrak yang dihasilkan.

Pada panjang gelombang $510 \mathrm{~nm}$ adalah panjang gelombang maksimum untuk sianidin-3glikosida sedangkan panjang gelombang $700 \mathrm{~nm}$ untuk mengoreksi endapan yang masih terdapat dalam sampel. Jika sampel benar-benar jernih maka absorbansi pada $700 \mathrm{~nm}$ adalah 0 (Suzery, M, et al.,2011). Hasil penelitian mengukur nilai absorbansi pada penelitian ini pada panjang gelombang 700 $\mathrm{nm}$ tidak memberikan nilai 0 , hal ini disebabkan pada sampel masih terdapat partikel-partikel kecil. Kadar antosianin yang diperoleh dari kulit buah manggis adalah 42,214 mg/l.

Ekstrak antosianin dari kulit buah manggis yang telah diperoleh selanjutnya diaplikasikan sebagai pewarna agar-agar. Agar-agar yang telah diberi pewarna kulit buah manggis dilakukan uji organoleptik terhadap warna dan rasa agar-agar. Warna agar-agar dari berbagai konsentrasi ekstrak kulit ditunjukkan pada Gambar 1.

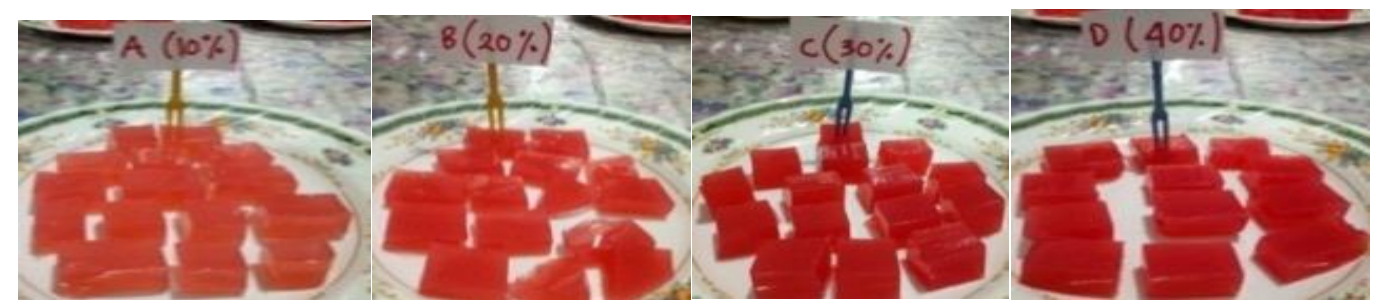

(a) (b) (c) (d)

Gambar 1. Warna agar-agar dari ekstrak kulit manggis pada konsentrasi (a) 10, (b) 20, (e) 30 dan (d) $40 \%$

Berdasarkan hasil uji organoleptik diperoleh hasil bahwa penambahan antosianin kulit buah manggis dengan konsentrasi 10\%, 20\%, 30\% dan 40\% berpengaruh terhadap warna agar-agar. Sedangkan penambahan antosianin kulit buah manggis dengan konsentrasi 10\%, 20\%, 30\% dan 40\% tidak berpengaruh terhadap rasa agar-agar. Konsentrasi ekstrak antosianin kulit buah manggis dalam agar-agar yang paling disukai dari 25 panelis adalah ekstrak antosianin kulit buah manggis dengan konsentrasi 10\%. Penelitian yang dilakukan Ninan, et al. (2014) tentang Stabilitas Antosianin Jantung Pisang Kepok (Musa paradisicia L) terhadap cahaya sebagai pewarna agar- agar hasil penelitian menunjukkan uji organoleptik agar-agar dengan variasi konsentrasi 15\%, 20\%, 25\%, 30\%, 40\%, dan $50 \%$. Konsentrasi ekstrak jantung pisang kepok dalam agar-agar yang paling disukai panelis adalah konsentrasi $25 \%$.

Penggunaan pewarna alami dari ekstrak antosianin kulit buah manggis sebagai pewarna pada makanan terdapat beberapa kelebihan seperti dapat digunakan sebagai pewarna alami yang dapat menggantikan pewarna sintetik, tidak berbahaya bagi tubuh karena pewarna yang digunakan adalah berasal dari bahan alam. Antosianin juga bersifat sebagai antioksidan yang secara tidak langsung dapat mengonsumsi zat antioksidan yang dibutuhkan tubuh.

Setelah penelitian laboratorium dilakukan selanjutnya pembuatan bahan ajar berdasarkan penelitian laboratorium. Bahan ajar yang dibuat adalah bahan ajar berupa poster. Gambar 2 menunjukkan hasil poster dari hasil penelitian laboratorium. Kompetensi dasar pada kurikulum 2013 kelas X mata pelajaran Kimia diletakkan paling atas pada poster. 


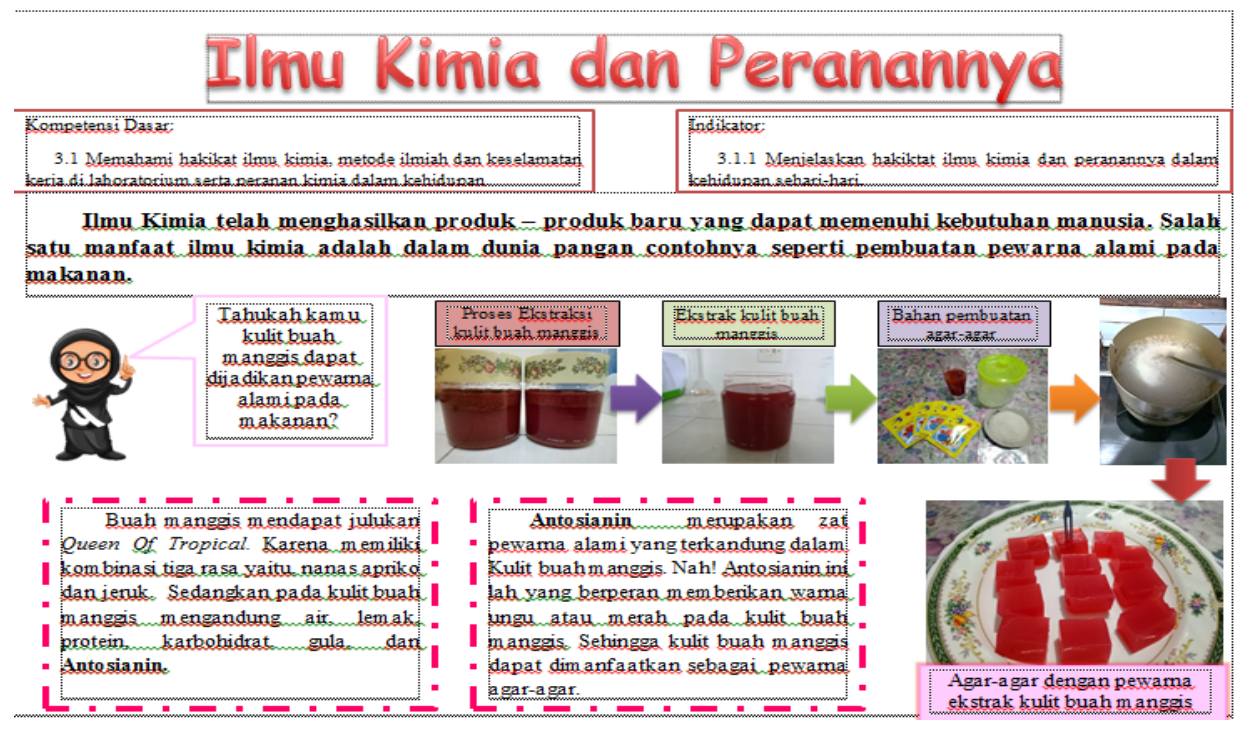

Gambar 2. Struktur bahan ajar pada poster

Judul pada poster dapat diambil pada materi pokok, materi pokoknya adalah Ilmu Kimia dan Peranannya. Informasi pendukung berupa pengetahuan yang akan diberikan kepada peserta didik berupa peranan ilmu kimia dalam kehidupan, penjelasan mengenai manggis, penjelasan mengenai kandungan kulit senyawa yang terdapat pada kulit buah manggis serta gambar pendukung hasil pewarnaan agar-agar dengan menggunakan kulit buah manggis.

Pada poster menyampaikan informasi yang terkait pemanfaatan antosianin dari kulit buah manggis sebagai pewarna agar-agar, menjelaskan tentang antosianin dan menyertakan animasi serta gambar proses pembuatan ekstrak antosianin sebagai pewarna agar-agar. Peserta didik dapat menghubungkan pembelajaran kimia dengan kehidupan sehari-harinya. Dimana peserta didik dapat mengaplikasikan penggunaan pewarna alami dari kulit buah manggis sebagai pewarna alami yang lebih sehat pengganti pewarna sintesis. Pembelajaran yang dihubungkan dengan kehidupan seharihari atau kehidupan nyata peserta didik dapat meningkatkan motivasi peserta didik. Berdasarkan hasil penelitian yang dilakukan Lilia dan Widodo, (2014) implementasi pembelajaran kontekstual pada materi reaksi redoks dengan percobaan sederhana berbasis alam lingkungan mampu meningkatkan motivasi belajar peserta didik. Hal ini karena peserta didik dapat langsung menghubungkan materi reaksi redoks dengan contoh yang terdapat di lingkungan sehari-hari peserta didik melalui percobaan sederhana. Mengaitkan konten mata pelajaran dengan kehidupan sehari-hari atau kehidupan nyata peserta didik dapat meningkatkan motivasi peserta didik dalam menghubungkan antara pengetahuan dan penerapannya dalam kehidupan sehari-hari peserta didik sebagai seorang anggota keluarga, warga negara dan juga tenaga kerja (Wulandari, 2019).

\section{c. Evaluasi Bahan Ajar}

Evaluasi bahan ajar dilakukan berdasarkan ketersediaan poster, kesesuaian isi poster dan penggunaan poster sebagai bahan ajar. Validasi poster divalidasi oleh validator untuk mendapatkan tingkat kevalidan bahan ajar sehingga bahan ajar dapat digunakan dalam proses pembelajaran. Hasil validasi dengan menggunakan rating scale. Validator memberikan penilaian tampilan keseluruhan poster dengan cara memilih kriteria Validasi bahan ajar berupa poster dilakukan dua kali tahapan revisi, setelah tahap revisi terakhir didapatkan rekapitulasi data hasil penilaian validasi bahan ajar. Hasil validasi didapatkan persentase keidealan $80 \%$ dengan kategori valid.

Berdasarkan hasil penelitian Dityatulloh, et al., (2018) tentang pengembangan media pembelajaran poster pada mata pelajaran sensor dan actuator kelas XI SMK Negeri 1 Labang Bangkalan hasil validasi oleh validator menunjukkan nilai rata-rata sebesar $80 \%$ yang dikategorikan baik. Berdasarkan penelitian yang dilakukan Rizawayani, et al. (2017) tentang tentang pengembangan 
media poster pada materi struktur atom di SMA Negeri 12 Banda Aceh hasil validitas menunjukkan nilai rata-rata $82,53 \%$ yang dikategorikan bahwa media poster yang dikembangkan sangat layak dan dapat digunakan sebagai media pembelajaran dan merupakan bahan ajar yang dapat menerapkan konsep materi yang abstrak sehingga dapat membantu peserta didik dalam memahami materi struktur atom dengan baik dan optimal. Penelitian bahan ajar poster yang dilakukan oleh Soebroto, et al (2009) tentang pembelajaran media visual yang dapat berupa poster, gambar, chart, sketsa di ruang kelas berpengaruh terhadap minat dan hasil belajar kimia peserta didik pada materi larutan elektrolit dan reaksi oksidasi-reduksi. Besar pengaruh media visual terhadap minat dan hasil belajar peserta didik pada materi larutan elektrolit dan reaksi oksidasi-reduksi adalah 74,5184\% dan 57,2964\%.

\section{KESIMPULAN}

Hasil ekstrak antosianin dari kulit buah manggis yang diperoleh dan dihitung menggunakan metode $\mathrm{pH}$ diferensial sebesar 42,214 mg/l. Uji organoleptik yang dilakukan terhadap 25 panelis agak ahli terhadap rasa agar-agar dengan penambahan ekstrak antosianin kulit buah manggis dengan persentase 10, 20,30 dan $40 \%$, hasil yang paling disukai panelis adalah dengan penambahan ekstrak antosianin kulit buah manggis $10 \%$. Penambahan konsentrasi ekstrak kulit buah manggis dari variasi yang berbeda berpengaruh tidak berpengaruh terhadap rasa agar-agar berdasarkan hasil uji hedonik. Hasil penelitian pemanfaatan ekstrak antosianin dari kulit buah manggis untuk pewarna agar-agar dapat dijadikan sebagai bahan ajar berupa poster pada materi ilmu kima dan peranannya. Hasil validasi oleh validator didapatkan persentase $80 \%$ dengan katagori valid.

\section{DAFTAR PUSTAKA}

Ayustaningwarno, F. 2014. Teknologi Pangan; Teori Praktis dan Aplikasi.Graha llmu. Yogyakarta.

Daesusi, Ruspeni., \& Ghoni, A. (2018). pengaruh pemberian kulit buah durian (Durio zibethinus) terhadap aktivitas semut rangrang (oecophylla smaragdina) dan pemanfaatannya sebagai bahan ajar mata kuliah pengelolaan limbah. Pedago Biologi, 5(1).

Dityatulloh, S.R dan Santosa. A.B 2018. Pengembangan Media Pembelajaran Poster Pada Mata Pelajaran Sensor dan Aktuator Kelas XI TEI SMK Negerri 1 Lambang Bangkalan. Jurnal Pendidikan Teknik Elektro.7(2): 166-173.

Fauziyah, N.A., Saleh, C., Erwin. 2016. Ekstraksi dan Uji Stabilitas Zat Warna dari Kulit Buah Alpukat (Persea americana Mill) dengan metode spektroskopi UV-VIS. Jurnal Atomatik. 1(1). 23-27.

Gupita, C. N. 2012. Pengaruh Berbagai pH Sari Buah dan Suhu Pasteurisasi terhadap Aktivitas Antioksidan dan Tingkat Penerimaan Sari Kulit Buhah Manggis. Skripsi. Universitas Diponegoro. Semarang.

Hartono, R. 2013. Ragam Model Mengajar yang Mudah Diterima Murid. Diva press. Yogyakarta.

Hayati, E.K., Budi, U.S., Hermawan, R. 2012. Konsentrasi Total Senyawa Antosianin Ekstrak Kelopak Bunga Rosella (Hibiscus sabdariffa L.): Pengaruh Temperatur dan pH. Jurnal Kimia, 6(2). 138-147.

Jaedun, A. 2010. Pemanfaatan Teknologi Informasi dan Komunikasi Sebagai Sumber Belajar Alternatif. Diklat Pemanfaatan Sumber Belajar yang Kreatif. Yogyakarta, 14 Maret 2010.

Lilia, L., Widodo, A.T. 2014. Implementasi Pembelajaran Kontekstual Dengan Strategi Percobaan Sederhana Berbasis Alam Lingkungan Siswa Kelas X. Jurnal Inovasi Pendidikan Kimia. 8(2): 1351-1359.

Maulidiyah, I. 2012. Kajian Tentang Daya Antibakteri Ekstrak Kulit Buah Manggis (Garcinia mangostana L) Bentuk Segar dan Kering dalam beberapa Macam Konsentrasi terhadap Shigella dysentriae Sebagai Bahan Ajar Mikrobiologi. Tesis Program Pascasarjan UM. Malang.

Mulyasa, E. 2013. Pengembangan dan Implementasi Kurikulum 2013. PT Remaja Rosdakarya. Bandung. 
Ninan, L,N., Martius, K.W.C.Y., Augustinus, I.K. 2014. Stabilitas Antosianin Jantung Pisang Kepok (Musa paradisicia L) Terhadap Cahaya Sebagai Pewarna Agar- agar. Agritech. 34(4): 374381.

Niska, B. dan Jandut, G. 2013. Penggunaan Media Poster Untuk Peningkatan Hasil Belajar Siswa Pada Pelajaran Pendidikan Kewarganegaraan di Sekolah Dasar. Jurnal Pendidikan Guru Sekolah Dasar. 1(2): 0-216

Prastowo,A. 2004. Panduan Kreatif Membuat Bahan Ajar. Diva Press. Yogyakarta.

Riduwan. 2007. Skala Pengukuran Variabel-variabel Penelitian. Alfabet. Bandung

Rizawayani, Sari, A.S., Safitri, R. 2017. Pengambangan Media Poster Pada Materi Struktur Atom di SMA Negeri 12 Banda Aceh. Jurnal Pendidikan Sains Indonesia. 5(1): 127-133.

Santoni, A., Darwis, D., Syahri, S. 2013. Isolasi Antosianin dari Buah Pucuk Merah (Syzygium campanulatum khort.) Serta Pengujian Antioksidan dan Aplikasi sebagai Pewarna Alami. Prosiding Semirata FMIPA Universitas Lampung. Lampung, 10-12 Mei 2013.

Sari, L.A., Widyaningrum. T., 2014. Uji Patogenitas Spora Jamur Metrhizium anisopliae terhadap mortalitas Hama Hypothenemus hampei (Ferrari) Sebagai Bahan Ajar Biologi SMA Kelas X. JUPEMASI-PBIO. 1(1): 26-32.

Siregar, S. 2013. Metode Penelitian Kuantitatif: Dilengkapi Perbandingan Perhitungan Manual \& SPSS. Kencana. Jakarta.

Soebroto, T., Priatmoko, S., Siyamita, N. 2009. Pengaruh Media Visual di Ruang Kelas Terhadap Minat dan Hasil Belajar Kimia Siswa. Jurnal Inovasi Pendidikan Kimia. 3(1): 400-405

Sukhriwarti, D. 2015. Mengkombinasi Agar-agar dengan Sayuran Menjadi Makanan Sehat. Jurnal Nasional Ecopedon. 3(1): 124-127.

Supiyanti,W. 2010. Uji Aktivitas Antioksidan dan Penentuan Kandungan Antosianin Total Kulit Buah Manggis (Garcinia mangostana L). Majalah Obat Tradisional, 15(2): 67.

Suzery, M., Lestarti, S., Cahyono, B. 2011. Penentuan Total Antosianin dari Kelopak Bunga Rosela (Hibiscus sabdariffa L) dengan Metode Maserasi dan Sokshletasi. Jurnal Sains dan Matematika. 18(1): 138-147.

Wulandari, R. 2016. Pengaruh berbagai konsentrasi Ekstrak Bunga Mawar Merah (Rosa damascene Mill) terhadap Stabilitas Warna Antosianin Agar-agar sebagai Sumber Belajar Biologi. Jurnal Pendidikan Biologi Indonesia. 2(1): 48-56.

Wulandari, F., Juniar, A., Ayurosalia, A.V. 2019. Pengembangan Modul Berbasis Kontekstual Pada Materi Koloid Di Sekolah Menengah Atas. Talenta Conference Series Science and Technology. 2(1): 272-278

Wulaningrum, R, A. 2013. Pengaruh Asam Organik dalam Ekstraksi Zat Warna Kulit Buah Manggis (Garcinia mangostana). Indonesian Journal of Chemical Science. 2(2): 119-124. 